\title{
A Study on Relationship between Parity and Milk Yield, Fat and Solids-Not-Fat Percent in Murrah Graded Buffaloes under Field Conditions
}

\author{
B. Ranjitha ${ }^{1}$, P. Ashalatha ${ }^{*}$, S. Jagadeeswararao ${ }^{1}$ and B. Subrahmanyeswari ${ }^{2}$ \\ ${ }^{1}$ Department of LPM, ${ }^{2}$ Department of VAE, NTR College of Veterinary Science, Gannavaram, \\ Krishna District, Andhra Pradesh, India
}

Corresponding author

\section{A B S T R A C T}

\section{Keyw ords \\ Parity, Milk yield, Fat percent, SNF percent, Murrah graded buffaloes \\ Article Info \\ Accepted: \\ 04 November 2020 \\ Available Online: \\ 10 December 2020}

\begin{abstract}
The present experiment was carried to study the relationship of animal parity with milk yield, fat and solids-not-fat percent in murrah graded buffaloes under field conditions. In this, 150 murrah graded buffaloes of different parities $\left(1^{\text {st }}\right.$ to $6^{\text {th }}$ parities $)$ from different commercial farms of Guntur and Krishna districts were selected. Various parameters like parity related to average milk yield, fat percent, SNF percent was taken into consideration for the present study. There was an increase in udder length, udder width and from $2^{\text {nd }}$ parity to $6^{\text {th }}$ parity but there is decrease from 1 st parity to $2^{\text {nd }}$ parity. Udder depth increased from $1^{\text {st }}$ parity to $6^{\text {th }}$ parity. Average daily milk yield increased from $1^{\text {st }}$ to $6^{\text {th }}$ parity. There was an increase in fat and SNF per cent from $1^{\text {st }}$ to $5^{\text {th }}$ parity and there is decrease from $6^{\text {th }}$ parity. High positive correlation was observed between parity and milk yield and SNF percent.
\end{abstract}

\section{Introduction}

The world buffalo population is found to be 199.784 million (FAO 2015) and 56.6\% Buffaloes are in India. During the last 10 years, an annual growth of buffalo population was $1.49 \%$ and $1.53 \%$ in the world and India respectively. There are 108.70 million buffaloes in India which contribute $21.23 \%$ of the total livestock population in India. The female buffalo population has increased by $7.99 \%$ over the previous census and the total number of female buffalo is 92.5 million in 2012 (19th livestock census). India ranks first among the world's milk producing nations with production of 146.3 million tons during
2014-15 and contributing 17.4\% of world milk production.

The buffalo milk alone contributes $51 \%$ of the total milk production in the India. Andhra Pradesh endowed with buffalo population of 10.6 million with a milk production of 7.4 metric tonnes (GOI 2017). About $72 \%$ of the milk produced in Andhra Pradesh comes from the buffaloes. It is one of the major buffalo milk producing states of the country.

Buffaloes are preferred over cattle in India because of their distinctive qualities such as better feed conversion efficiency, more resistance to diseases and higher milk fat 
percentage than in cows. Moreover, buffalo can efficiently convert low quality feed stuffs like straws and agro industrial waste into human food and improve soil structure through bio fertilizer.

When the buffalo rearing has shifted from the backyard to commercial farms, popularity of buffalo milk has ensured buffalo production as a main stay in the path of the dairy industry in India. However, for this species to perform optimally under the pressure of intensive production systems, the animals have to be improved with clear focus on the desired output.

\section{Materials and Methods}

A total of one hundred and fifty lactating Murrah graded buffaloes with different parities of various buffalo farms located at various villages like Balusulapalem, Bhattiprolu, Nagaram, Borravaripalem, Dosapalem, Pudivada and Uppuluru were utilized for this study and presented in the Table 1.

\section{Test day milk yield, fat and snf per cent}

The test day milk yield of the particular buffalo was measured and recorded on the same day. The milk samples were collected for estimation of fat per cent and this was done by using the automatic milk fat analyzer on the same day at the local collection centres.

The SNF content of the milk was estimated by using the following Richmond's formula.

$$
\mathrm{SNF} \%=\frac{\mathrm{CLR}}{4}+0.21 \mathrm{~F}+0.14
$$

CLR: Corrected Lactometer Reading

F: Fat per cent

\section{Results and Discussion}

Effect of parity order on udder measurements milk yield, fat and snf percent

\section{Frequency of parity order}

Distribution of experimental animals according to various parities were presented in the Table 2. Among 150 Graded Murrah Buffaloes 43 buffaloes are in 3rd parity, 41buffaloes are in 4th parity, 28 buffaloes are in 5th parity, 23 buffaloes are in 2ndparity, 10 buffaloes are in 6th parity and 5 buffaloes are in 1st parity.

\section{Udder and Teat measurements according to their parities}

Different Udder measurements according to parity order in Murrah Graded Buffaloes are presented in the Table 3. In this study the Udder Length and Udder width ranged from $46.00 \pm 0.75$ and $40.86 \pm 0.76 \mathrm{~cm}$ to $51.30 \pm 1.3$ and $45.50 \pm 1.52 \mathrm{~cm}$, respectively. Udder depth also varied from $11.6 \pm 0.18$ to $12.25 \pm 0.18 \mathrm{~cm}$. Udder Length and Udder width in 1st parity buffaloes were $46.40 \pm 1.63$ and $41.20 \pm 1.02$ $\mathrm{cm}, 2$ nd parity buffaloes were $46.00 \pm 0.75$ and $40.86 \pm 0.76 \mathrm{~cm}$, 3rd parity buffaloes were $46.69 \pm 0.55$ and $41.41 \pm 0.70 \mathrm{~cm}$, 4th parity buffaloes were $48.80 \pm 0.70$ and $43.51 \pm 0.69$ $\mathrm{cm}, 5$ th parity buffaloes were $50.10 \pm 0.51$ and $44.82 \pm 0.57$, 6th parity buffaloes were $51.30 \pm 1.35 \mathrm{~cm}$ and $45.50 \pm 1.39 \mathrm{~cm}$. Similarly, the Udder depth in 1 st parity was $11.6 \pm 0.18$, 2nd 11.65 $\pm 0.11,3 \mathrm{rd} \quad 11.65 \pm 0.09, \quad 4$ th $11.82 \pm 0.10, \quad 5$ th $12.00 \pm 0.08$ and 6 th $12.25 \pm 0.18 \mathrm{~cm}$, respectively.

It is concluded that there was an increase in Udder length and Udder width from 2nd parity to 6th parity but there was decrease from 1st parity to 2 nd parity. Udder depth increases from 1 st parity to 6 th parity. Teat 
lengths of various parities in Murrah Graded Buffaloes are presented in the Table 4. There is increase in measurements from first parity to sixth parity. Maximum teat lengths were observed in sixth parity with the mean values of right fore teat, left fore teat, right rear teat and left rear teat as $5.76 \pm 0.03,5.95 \pm 0.06$, $6.14 \pm 0.06$ and $6.38 \pm 0.07 \mathrm{~cm}$ respectively. As the parity increases, there was increase in length of teats. Teat diameter of various parities was presented in the Table 5 . Maximum teat diameter was observed in sixth parity with the mean values of $2.56 \pm 0.03$, $2.72 \pm 0.03, \quad 2.92 \pm 0.04$ and $3.12 \pm 0.07 \mathrm{~cm}$ respectively for Right Fore teat, left fore teat, right rear teat and left rear teat. It was observed that as the parity increases the diameter also increases.

Table.1 Table showing the number of animals assessed in the villages of Guntur and Krishna districts

\begin{tabular}{|l|l|c|}
\hline Village & District & No. of animals assessed \\
\hline Balusulapalem & Guntur & 10 \\
\hline Bhattiprolu & Guntur & 40 \\
\hline Nagaram & Guntur & 20 \\
\hline Borravaripalem & Guntur & 20 \\
\hline Dosapalem & Guntur & 20 \\
\hline Pudivada & Guntur & 20 \\
\hline Uppuluru & Krishna & 20 \\
\hline
\end{tabular}

Table.2 Distribution of animals according to parity in Murrah Graded Buffaloes

\begin{tabular}{|c|c|c|}
\hline Parity & No. of animals & Percentage \\
\hline $\mathbf{1}$ & 5 & 3 \\
\hline $\mathbf{2}$ & 23 & 15 \\
\hline $\mathbf{3}$ & 43 & 29 \\
\hline $\mathbf{4}$ & 41 & 27 \\
\hline $\mathbf{5}$ & 28 & 19 \\
\hline $\mathbf{6}$ & 10 & 7 \\
\hline
\end{tabular}

Table.3 Udder measurements ( $\mathrm{cm}$ ) according to parities in Murrah Graded Buffaloes (Mean \pm S.E)

\begin{tabular}{|l|l|l|l|}
\hline Parity & Udder Length & Udder width & Udder depth \\
\hline $\mathbf{1}$ & $46.40 \pm 1.6$ & $41.20 \pm 1.02$ & $11.60 \pm 0.18$ \\
\hline $\mathbf{2}$ & $46.00 \pm 0.75$ & $40.86 \pm 0.76$ & $11.65 \pm 0.11$ \\
\hline $\mathbf{3}$ & $46.69 \pm 0.55$ & $41.41 \pm 0.70$ & $11.65 \pm 0.09$ \\
\hline $\mathbf{4}$ & $48.80 \pm 0.70$ & $43.51 \pm 0.69$ & $11.82 \pm 0.10$ \\
\hline $\mathbf{5}$ & $50.10 \pm 0.51$ & $44.82 \pm 0.57$ & $12.00 \pm 0.08$ \\
\hline $\mathbf{6}$ & $51.30 \pm 1.35$ & $45.50 \pm 1.39$ & $12.25 \pm 0.18$ \\
\hline
\end{tabular}


Table.4 Teat Lengths according to various parities in Murrah Graded Buffaloes (Mean \pm S.E)

\begin{tabular}{|c|c|c|c|c|}
\hline Parity & Right Fore & Left Fore & Right Rear & Left Rear \\
\hline $\mathbf{1}$ & $5.20 \pm 0.08$ & $5.32 \pm 0.08$ & $5.46 \pm 0.06$ & $5.62 \pm 0.08$ \\
\hline $\mathbf{2}$ & $5.21 \pm 0.04$ & $5.39 \pm 0.04$ & $5.43 \pm 0.13$ & $5.74 \pm 0.07$ \\
\hline $\mathbf{3}$ & $5.33 \pm 0.04$ & $5.51 \pm 0.01$ & $5.67 \pm 0.02$ & $5.86 \pm 0.03$ \\
\hline $\mathbf{4}$ & $5.48 \pm 0.03$ & $5.67 \pm 0.03$ & $5.82 \pm 0.03$ & $6.00 \pm 0.04$ \\
\hline $\mathbf{5}$ & $5.57 \pm 0.03$ & $5.72 \pm 0.03$ & $5.91 \pm 0.03$ & $6.13 \pm 0.04$ \\
\hline $\mathbf{6}$ & $5.76 \pm 0.03$ & $5.95 \pm 0.06$ & $6.14 \pm 0.06$ & $6.38 \pm 0.07$ \\
\hline
\end{tabular}

Table.5 Teat diameter according to various parities in Murrah Graded Buffaloes (Mean \pm S.E)

\begin{tabular}{|l|l|l|l|l|}
\hline Parity & Right Fore & Left Fore & Right Rear & Left Rear \\
\hline $\mathbf{1}$ & $2.32 \pm 0.02$ & $2.40 \pm 0.05$ & $2.50 \pm 0.14$ & $2.6 \pm 0.10$ \\
\hline $\mathbf{2}$ & $2.38 \pm 0.01$ & $2.46 \pm 0.01$ & $2.55 \pm 0.03$ & $2.61 \pm 0.03$ \\
\hline $\mathbf{3}$ & $2.44 \pm 0.01$ & $2.56 \pm 0.01$ & $2.67 \pm 0.02$ & $2.83 \pm 0.03$ \\
\hline $\mathbf{4}$ & $2.50 \pm 0.01$ & $2.61 \pm 0.01$ & $2.74 \pm 0.02$ & $2.89 \pm 0.02$ \\
\hline $\mathbf{5}$ & $2.58 \pm 0.01$ & $2.74 \pm 0.01$ & $2.86 \pm 0.02$ & $3.08 \pm 0.03$ \\
\hline $\mathbf{6}$ & $2.56 \pm 0.03$ & $2.72 \pm 0.03$ & $2.92 \pm 0.04$ & $3.12 \pm 0.07$ \\
\hline
\end{tabular}

Table.6 Daily milk yield according to parity order in Murrah Graded Buffaloes (Mean \pm S.E)

\begin{tabular}{|c|c|c|}
\hline Parity & No. of animals & Daily milk yield(kg/day) \\
\hline $\mathbf{1}$ & 5 & $7.00 \pm 0.39$ \\
\hline $\mathbf{2}$ & 23 & $7.69 \pm 0.25$ \\
\hline $\mathbf{3}$ & 43 & $8.21 \pm 0.23$ \\
\hline $\mathbf{4}$ & 41 & $8.93 \pm 0.27$ \\
\hline $\mathbf{5}$ & 28 & $9.48 \pm 0.24$ \\
\hline $\mathbf{6}$ & 10 & $9.63 \pm 0.54$ \\
\hline
\end{tabular}

Table.7 Fat and SNF per cent according to parities in Murrah Graded Buffaloes

\begin{tabular}{|l|l|l|l|}
\hline Parity & No. of animals & Fat percent & SNF percent \\
\hline $\mathbf{1}$ & 5 & $7.00 \pm 0.14$ & $9.31 \pm 0.06$ \\
\hline $\mathbf{2}$ & 23 & $7.38 \pm 0.09$ & $9.36 \pm 0.04$ \\
\hline $\mathbf{3}$ & 43 & $7.43 \pm 0.07$ & $9.41 \pm 0.03$ \\
\hline $\mathbf{4}$ & 41 & $7.53 \pm 0.07$ & $9.44 \pm 0.02$ \\
\hline $\mathbf{5}$ & 28 & $7.54 \pm 0.05$ & $9.47 \pm 0.02$ \\
\hline $\mathbf{6}$ & 10 & $7.48 \pm 0.10$ & $9.43 \pm 0.04$ \\
\hline
\end{tabular}


Table.8 Relationship of parity with daily milk yield, fat, SNF and lactational yield in Murrah Graded Buffaloes

\begin{tabular}{|l|l|l|l|l|}
\hline Parameter & Parity & Milk yield & Fat & SNF \\
\hline Parity & 1 & $0.42^{* *}$ & $0.17^{*}$ & $0.18^{*}$ \\
\hline Milk yield & & 1 & $0.49^{* *}$ & $0.45^{* *}$ \\
\hline Fat & & & 1 & $0.78^{* *}$ \\
\hline SNF & & & 1 \\
\hline & & & \\
\end{tabular}

Fig.1 Average milk yield (kg/day) in different parities in murrah Graded Buffaloes

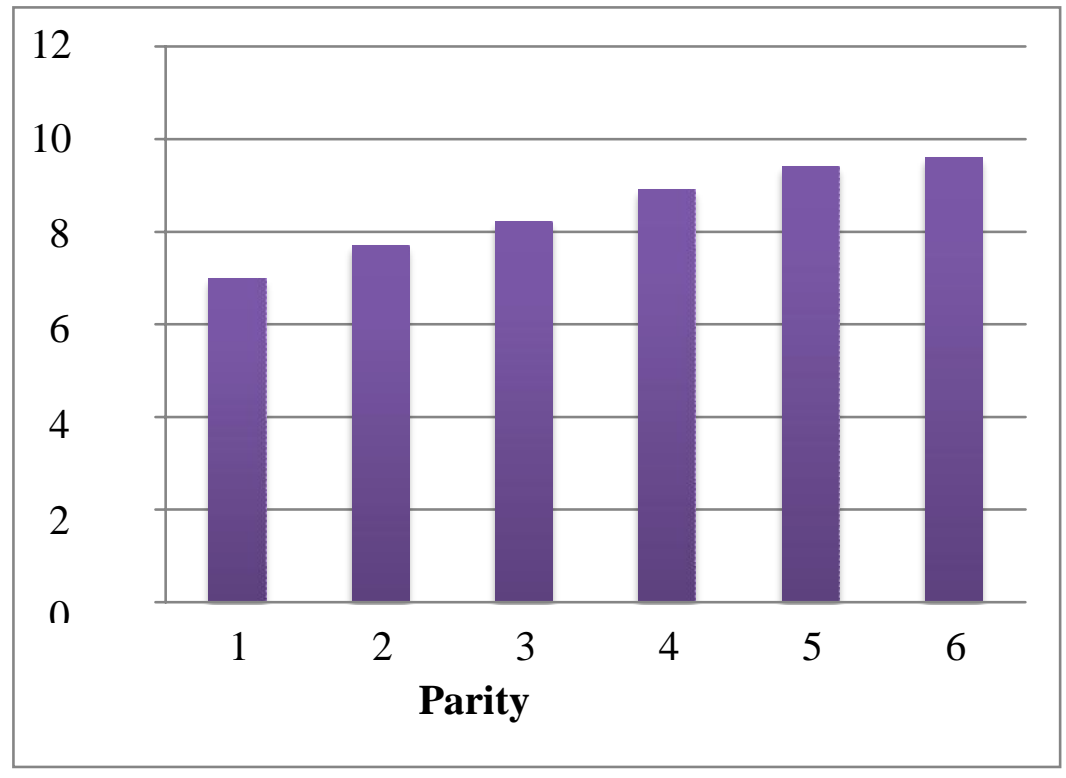

Average milk yield, fat and SNF per cent according to parity orders in Murrah Graded Buffaloes

Milk yield in various parities were presented in the Table 6 . It could be observed from the table that daily milk yield ranged from $7.00 \pm 0.39$ to $9.63 \pm 0.54 \mathrm{~kg}$. The average milk yield in 1st parity was $7.00 \pm 0.39$, 2nd $7.69 \pm 0.25,3$ rd $8.21 \pm 0.23$, 4th $8.93 \pm 0.27$, 5th $9.48 \pm 0.2$ and 6 th $9.63 \pm 0.54 \mathrm{~kg}$, respectively. Maximum and minimum milk yield were observed in 6th parity and 1st parity respectively. It was concluded that there is increase in milk yield from 1st to 6th parity.
Fat percent and SNF per cent according to various parities are presented in the Table 7. The fat and SNF values range from $7 \pm 0.14$ to $7.54 \pm 0.05$ and $9.31 \pm 0.06$ to $9.47 \pm 0.02$ per cent respectively. Fat and SNF per cent in 1st parity were $7.00 \pm 0.14$ and $9.31 \pm 0.06$, 2nd parity $7.38 \pm 0.09$ and $9.36 \pm 0.04$, 3rd parity $7.43 \pm 0.07$ and $9.41 \pm 0.03$, 4th parity $7.53 \pm 0.07$ and $9.44 \pm 0.02$, 5th parity $7.54 \pm 0.05$ and $9.47 \pm 0.02$ and 6th parity $7.48 \pm 0.10$ and $9.43 \pm 0.04$ respectively. It was concluded that there is increase in fat and SNF per cent from 1 st to 5th parity and there is decrease in 6th parity. 
Correlation of parity with daily milk yield, fat per cent and SNF per cent in Murrah Graded Buffaloes

The relationship of parity with daily milk yield, fat and SNF per cent was presented in the Table 8 . There was positive correlation of daily milk yield, fat and SNF per cent with parity. Parity showed high positive correlation with milk yield (0.42) and SNF per cent (0.18).

Parity effect on udder and teat measurements, milk yield, Fat per cent and SNF per cent in Murrah Graded Buffaloes

It could be informed that the udder length and udder width was ranged from $46 \pm 0.7597$ and $40.86 \pm 0.7630$ to $51.30 \pm 1.359$ and $45.50 \pm 1.526 \mathrm{~cm}$. Similarly, udder depth was $11.6 \pm 0.1871$ to $12.25 \pm 0.1863 \mathrm{~cm}$, respectively. It was concluded that there is an increase in udder length, udder width and from 2nd parity to 6th parity but there is decrease from 1st parity to 2nd parity. Udder depth increases from 1st parity to 6th parity. It was observed that there is increase of measurements from first parity to sixth parity. Maximum teat lengths were observed in sixth parity with the mean values of Right Fore Teat, Left Fore Teat, Right Rear Teat and Left Rear Teat were $5.76 \pm 0.03,5.95 \pm 0.06$, $6.14 \pm 0.06$ and $6.38 \pm 0.07 \mathrm{~cm}$, respectively. From Table 5 it was found that maximum teat diameter was observed in sixth parity with the mean values of Right Fore Teat, Left Fore Teat, Right Rear Teat and Left Rear Teat were $2.56 \pm 0.03 \mathrm{~cm}, 2.72 \pm 0.03 \mathrm{c}, 2.92 \pm 0.04 \mathrm{c}$ and $3.12 \pm 0.07 \mathrm{~cm}$. The results are in accordance with Akhtar et al., (1998) observed that the mean values of udder length, width, were $40.56 \pm 0.15,35.11 \pm$ 0.16 , respectively. The length and width of the udder increases upto fourth lactation. AlHered et al., (2005) observed that parity affected height and circumference of udder significantly $(\mathrm{p}<0.01)$. Deng et al., (2012) revealed that udder measurements increased with parity order. Zwertvaegher et al., (2012) suggested that teat length and diameter increased with parity, although the increase in teat length was not significant from second parity onwards in front teats. Bharti et al., (2015) concluded that udder morphological traits of Murrah Buffaloes varied from lactation to lactation order as the age advances. Khatri et al., (2017) concluded that multiparous Buffaloes had a significant $(\mathrm{P}<0.05)$ larger volume of udder than the primiparous Buffaloes.

\section{Daily milk yield, Fat per cent and SNF per cent in different parities in murrah Graded Buffaloes}

It was observed that the mean \pm S.E of test day milk in various parities were ranges from $7.00 \pm 0.39 \mathrm{~kg}$ to $9.63 \pm 0.54 \mathrm{~kg}$. Maximum and minimum milk yield was observed in 6th parity and 1st parity. It was concluded that there is increase in milk yield from 1st to 6th parity showed in Figure 1. It could be found that the mean \pm S.E of Fat per cent and SNF per cent according to various parities were ranges from $7 \pm 0.14$ to $7.54 \pm 0.05$ and $9.31 \pm 0.06$ to $9.47 \pm 0.02$ respectively. It was concluded that there is increase in Fat per cent and SNF per cent from 1st to 5th parity and there is decrease from 6th parity. It was found that parity showed positive correlation with daily milk yield, Fat and SNF per cent.

Thiruvenkadan et al., (2014) showed parity had a highly significant $(\mathrm{P}<0.01)$ effect on the yield increased from first to fourth parity and from there on it started declining. The 305day milk yield and lactation milk yield increased up to third parity, was maintained at fourth parity, and declined thereafter. Javed et al., (2013) Fat percentage was showed a positive association with age, body weight and lactation number. Singhai et al., (2013) 
found that cows in third parity have higher average daily milk yield followed by second, fourth and first. SNF percent was decreased order from first to fourth lactation whereas Fat $\%$ does not show any trend which was contrary to present findings.

\section{References}

Akhtar N, Thakuria K and Dos D 1999 Teat measurements and their relation with milk yield in swamp buffaloes. The Indian veterinary Journal 76(5):412416.

Al-Hered M A, Khalaf S S, Alkass J E and Juma K H 2005 Some Factors Related to Height and Circumference of Udders Among Lactating Holstein Cows. Jordan Journal of Agricultural Sciences Volume 1 No. 1 26-31.

Bharti P, Tomar A K, Verma M R, Bharti P K and Singh B P 2015 Effect of lactation order on morphological traits of teat and udder in Murrah buffaloes. Journal of Animal Research 5(3):561-565.

Deng M P, Badri T M, Atta M and Hamad M E 2012 Relationship between udder dimensions and milk yield of Kenanax Friesian crossbred cows. Research Opinions in Animal \& Veterinary Sciences 49-54 print ISSN 2221-1896.

FAO, 2012 Go A.P. 2015. Statistical Abstract of Andhra Pradesh, Directorate of Economics and Statistics, Government of Andhra Pradesh, Hyderabad.
Javed K, Abdullah M, Khalid M S, Ahmad N, Bhatti J A and Younas 2013 Interrelationship of milk constituents with body and udder measurements in NiliRavi buffaloes raised at commercial farms of Pakistan. Buffalo Bulletin 1170-1173.

Khatri, S B., Trivedi, M M., Patel, Y G. and Rajpura, R.M 2017 Udder and teat measurements and their relation with milk production in buffaloes. International Journal of Advanced Biological Research IJABR, VOL.7 (3): 582-584 ISSN 2250 - 3579.

Singhai S K, Ravikala K, Murthy K S, Gajbhiye $\mathrm{P}$ U, Vataliya $\mathrm{P} H$ and Savsani H H 2013 Udder teat morphology and body measurements and their relationship with milk yield and milking traits in Gir cows. Indian Journal of Animal Production and Management 29(1-2):5-11.

Thiruvenkadan A K, Panneerselvam S, Murali N, Selvam S, Saravanakumar VR 2014 Milk production and reproduction performance of Murrah buffaloes of Tamil Nadu, India. Buffalo Bulletin; 33(3): 291-300.

Zwertvaegher I, Van Weyenberg S, Piepers S, Baert J and De Vliegher S. 2012. Variance components of teat dimensions in dairy cows and associated factors. Journal of dairy science 95(9):4978-4988.

\section{How to cite this article:}

Ranjitha, B., P. Ashalatha, S. Jagadeeswararao and Subrahmanyeswari, B. 2020. A Study on Relationship between Parity and Milk Yield, Fat and Solids-Not-Fat Percent in Murrah Graded Buffaloes under Field Conditions. Int.J.Curr.Microbiol.App.Sci. 9(12): 301-307. doi: https://doi.org/10.20546/ijcmas.2020.912.040 